\title{
Effect of different extraction methods on trace metal elements content of Persian lime (Citrus latifolia) seed oil
}

\author{
Isa Fathollahy ${ }^{1, *}$ (D), Akram Pezeshki ${ }^{2}$ (D) and Saeed Mohammad Sorouraddin ${ }^{3}$ \\ ${ }^{1}$ Department of Food Science and Technology, Mamaghan Branch, Islamic Azad University, Mamaghan, Iran \\ 2 Department of Food Science and Technology, Faculty of Agriculture, University of Tabriz, Tabriz, Iran \\ ${ }^{3}$ Department of Analytical Chemistry, Faculty of Chemistry, University of Tabriz, Tabriz, Iran
}

Received 24 June 2021 - Accepted 29 August 2021

\begin{abstract}
The oil of Persian lime (Citrus latifolia) seed was extracted using three methods (coldpressing, solvent extraction and enzyme-assisted aqueous extraction using Protamex and Celluclast) to compare the effect of extraction method on oil quality through trace metal elements $(\mathrm{Fe}, \mathrm{Cu}, \mathrm{Ni}, \mathrm{Co}, \mathrm{Pb}$ and As) content. The results demonstrated that extraction method significantly $(P<0.05)$ influences the trace metal elements content of oil. The reduction pattern of $\mathrm{Fe}>\mathrm{Cu}>\mathrm{Ni}>\mathrm{Co}>\mathrm{Pb}>\mathrm{As}$ was observed in Persian lime seed and extracted oil samples. The highest concentration $(\mathrm{mg} / \mathrm{kg})$ of iron (7.3272 \pm 0.0263$)$, copper $(0.350033 \pm 0.00153)$ and lead $(0.00891 \pm 0.00003)$ were observed in cold pressed oils. The oils extracted using enzyme-assisted aqueous extraction method showed the highest concentration $(\mathrm{mg} / \mathrm{kg})$ of nickel $(0.069855 \pm 0.000167)$ and cobalt $(0.054555 \pm 0.000163)$. Arsenic was not detected in seeds and any of the extracted oil samples. The concentration of Fe $(3.0363 \pm 0.0423 \mathrm{mg} / \mathrm{kg})$ and $\mathrm{Cu}(0.280167 \pm 0.00151 \mathrm{mg} / \mathrm{kg})$ as a pro-oxidant was lower in the Persian lime seed oil obtained by enzymeassisted aqueous extraction method.
\end{abstract}

Keywords: Persian lime seed / trace metal elements / oil extraction method / cold-pressing / enzyme-assisted aqueous extraction

Résumé - Effet des méthodes d'extraction sur la teneur en éléments traces métalliques de l'huile de graines de lime de Perse (Citrus latifolia). L'huile de graines de lime de Perse (Citrus latifolia) a été extraite selon trois méthodes (pressage à froid, extraction par solvant et extraction aqueuse assistée par hydrolyse enzymatique par les enzymes Protamex ${ }^{\mathbb{B}}$ et Celluclast ${ }^{\mathbb{B}}$ ) afin de comparer l'effet de la méthode d'extraction sur la qualité de l'huile par le biais de la teneur en éléments traces métalliques (Fe, $\mathrm{Cu}, \mathrm{Ni}, \mathrm{Co}$, $\mathrm{Pb}$ et $\mathrm{As})$. Les résultats ont démontré que la méthode d'extraction influence significativement $(p<0,05)$ la teneur en éléments traces métalliques de l'huile. Par ordre d'importance, on a observé $\mathrm{Fe}>\mathrm{Cu}>\mathrm{Ni}>\mathrm{Co}>\mathrm{Pb}>\mathrm{As}$ pour les graines de lime persane et pour les échantillons d'huile extraits. Les concentrations les plus élevées (en $\mathrm{mg} / \mathrm{kg}$ ) en fer $(7,3272 \pm 0,0263)$, cuivre $(0,350033 \pm 0,00153)$ et plomb $(0,00891 \pm 0,00003)$ ont été observées dans les huiles pressées à froid. Les huiles extraites par la méthode d'extraction aqueuse assistée par hydrolyse enzymatique ont montré les plus fortes concentrations $(\mathrm{mg} / \mathrm{kg})$ en nickel $(0,069855 \pm 0,000167)$ et cobalt $(0,054555 \pm 0,000163)$. L'arsenic n'a pas été détecté dans les graines ni dans aucun des échantillons d'huile extraits. La concentration en éléments pro-oxydants : $\mathrm{Fe}(3,0363 \pm 0,0423 \mathrm{mg} / \mathrm{kg})$ et $\mathrm{Cu}(0,280167 \pm 0,00151 \mathrm{mg} / \mathrm{kg})$ était plus faible dans l'huile de graines de lime perse obtenue par la méthode d'extraction aqueuse assistée par hydrolyse enzymatique.

Mots clés : Citrus latifolia / éléments traces métalliques / méthode d'extraction de l'huile / pressage à froid / extraction aqueuse assistée par hydrolyse enzymatique

*Correspondence: isa.fathollahy@gmail.com, isa.fathollahy@iaumamaghan.ac.ir 


\section{Highlights}

Cold-pressing, solvent extraction and enzymeassisted aqueous extraction method was used to extract Persian lime seed oil.

Extraction method of Persian lime seed oil significantly affected the trace metal content.

The reduction pattern of $\mathrm{Fe}>\mathrm{Cu}>\mathrm{Ni}>\mathrm{Co}>\mathrm{Pb}>$ As was observed in Persian lime seed and extracted oil samples.

The amount of $\mathrm{Fe}, \mathrm{Cu}$ as pro-oxidant was lower in the Persian lime seed oil obtained by enzyme-assisted aqueous extraction method.

The type of enzyme used in the enzyme-assisted aqueous extraction method significantly affected the content of trace metals.

\section{Introduction}

Citrus seed such as Persian lime (Citrus latifolia) seed, as a valuable by-products of citrus processing, remained after the citrus juice extraction process. Because of high oil content (Juhaimi et al., 2016; Yilmaz and Güneser 2017; Fathollahi et al., 2021) citrus seed is interesting especially for oil extraction to use in the formulation of various food products, detergents, cosmetics and soaps. According to Fathollahi et al. (2021), palmitic (27.09-28.36\%), oleic (26.01-26.62\%) and linoleic (30.72-31.48\%) acids were the main fatty acids of solvent extracted and cold-pressed oils of Persian lime seed that makes it as a good candidate for cooking and frying applications. Because of great importance of vegetable oils (especially oils with a new source such as citrus seed oil) for various industries, including food, pharmaceutical, cosmetic and chemical industries (Dugo et al., 2004), oil quality and its stability are very important for the consumer's desirable use. Along properties including peroxide value, iodine value, free fatty acid, saponification value, color appearance, etc., one of the most important and vital quality properties of vegetable oils is its metal content (Ennoukh et al., 2017). Both endogenous and exogenous factors (plant metabolism and genotype, soil, water, environment, fertilizer or pesticides, production and the collection process, oil extraction and treatment processes and systems and materials of packaging), influence the presence of metals in vegetable oils (Lo Coco et al., 2003; Dantas et al., 2003; Zeiner et al., 2005; Jamali et al., 2008). Trace metal elements can be classified as potentially toxic (arsenic, cadmium, lead, etc.), probably essential (vanadium, cobalt) and essential (copper, zinc, iron, manganese, etc.). Aiming to assess health risks, eight heavy metals $(\mathrm{Cu}, \mathrm{Zn}, \mathrm{Fe}, \mathrm{Mn}, \mathrm{Cd}, \mathrm{Ni}$, $\mathrm{Pb}$ and $\mathrm{As}$ ), were determined in nine varieties of edible vegetable oils collected from China. The results showed that the dietary intakes of the eight heavy metals from weekly consumption of $175 \mathrm{~g}$ of edible vegetable oils or daily consumption $25 \mathrm{~g}$ of edible vegetable oils for a $70 \mathrm{~kg}$ individual should pose no risk to human health (Zhu et al., 2011). Therefore, the assessment of trace metal elements levels in vegetable oils with new sources, reporting possible contamination, and evaluation of methods to eliminate or reduce the content of toxic trace metal elements is necessary. Toxic elements can be very harmful even at low concentration if consumed with contaminated materials (such as food and cosmetics) for a long time (Gopalani et al., 2007). One of the most important factors that significantly influence metal contents of edible oils is the oil extraction method. Traditional methods, solvent extraction, cold-pressing, enzymatic extraction, and supercritical-fluid extraction are edible oil extraction methods. The aim of present study is to investigate the effect of the oil extraction method (cold-pressing, solvent extraction and enzyme-assisted aqueous extraction) on Persian lime seed oil trace metal elements content.

\section{Materials and methods}

\subsection{Materials and chemicals}

Persian lime (C. latifolia) seeds were collected from waste (composed of peels, seeds, and pulp) of a lime juice extraction plant (Asiashoor Food Industry and Trade Inc., Tabriz, Iran). The seeds were first poured in water and stirred using a spatula to help detachment of seed from the other materials. Protamex (1.5 AU/g; combined proteases) and Celluclast $1.5 \mathrm{~L}(700 \mathrm{EGU} / \mathrm{g})$ were kindly provided by Novozymes (Bagsvaerd, Denmark). $A s_{2}(O)_{3} \quad\left(M_{w}=197.841 \mathrm{~g} / \mathrm{mol}\right)$, $\mathrm{Fe}(\mathrm{Cl})_{3} 6 \mathrm{H}_{2} \mathrm{O} \quad\left(\mathrm{M}_{w}=270.295 \mathrm{~g} / \mathrm{mol}\right), \quad \mathrm{Cu}\left(\mathrm{NO}_{3}\right)_{2} 3 \mathrm{H}_{2} \mathrm{O}$ $\left(M_{w}=241.601 \mathrm{~g} / \mathrm{mol}\right), \quad \mathrm{Pb}\left(\mathrm{NO}_{3}\right)_{2} \quad\left(M_{w}=331.200 \mathrm{~g} / \mathrm{mol}\right)$, $\mathrm{Co}\left(\mathrm{NO}_{3}\right)_{2} 3 \mathrm{H}_{2} \mathrm{O} \quad\left(\mathrm{M}_{w}=291.030 \mathrm{~g} / \mathrm{mol}\right), \quad \mathrm{Ni}\left(\mathrm{NO}_{3}\right)_{2} 6 \mathrm{H}_{2} \mathrm{O}$ $\left(M_{w}=290.790 \mathrm{~g} / \mathrm{mol}\right.$ ), and $\mathrm{HNO}_{3}$ (Merck, Darmstadt, Germany) were used for preparation of standard solutions.

\subsection{Proximate composition of seeds}

Moisture, protein, ash, and fat content of samples were measured using methods $\mathrm{Ca} 2 \mathrm{~d}-25, \mathrm{Ba} 4 \mathrm{~d}-90$, Ba 5a-49, Am 2-93 American Oil Chemists' Society, respectively (AOCS, 1997). Total carbohydrate was measured according to Herbert et al. (1971).

\subsection{Extraction of Persian lime seed oil}

\subsubsection{Cold-pressing}

The cold-pressed extraction of oil was performed using the method of Fathollahi et al. (2021). At first using the following equation moisture content of the seeds was adjusted to $8 \%$ and the seeds were conditioned in polyethylene bags $\left(4^{\circ} \mathrm{C}, 48 \mathrm{~h}\right)$ :

$$
Q=\frac{W_{i}\left(M_{f}-M_{i}\right)}{100-M_{f}}
$$

where $Q$ is the mass of water added $(\mathrm{kg}), W_{i}$ is initial mass of sample $(\mathrm{kg}), M_{i}$ is initial moisture content ( $\%$ dry basis) of the sample, $M_{f}$ is final moisture content ( $\%$ dry basis) of the sample. A laboratory-scale cold-press machine (Iran cold pressing, Kerman, Iran; single head, $0.75 \mathrm{~kW}$ power, $10 \mathrm{~kg} \mathrm{seed} / \mathrm{h}$ capacity) at $10 \mathrm{rpm}$ screw rotation speed was used to cold-pressing. The temperature of oil was maintained below $45^{\circ} \mathrm{C}$ during the pressing process. 
Table 1. Instrument settings and furnace programs for analysis of $\mathrm{Cu}, \mathrm{Pb}, \mathrm{As}, \mathrm{Co}, \mathrm{Ni}$, and $\mathrm{Fe}$ by GFAAS.

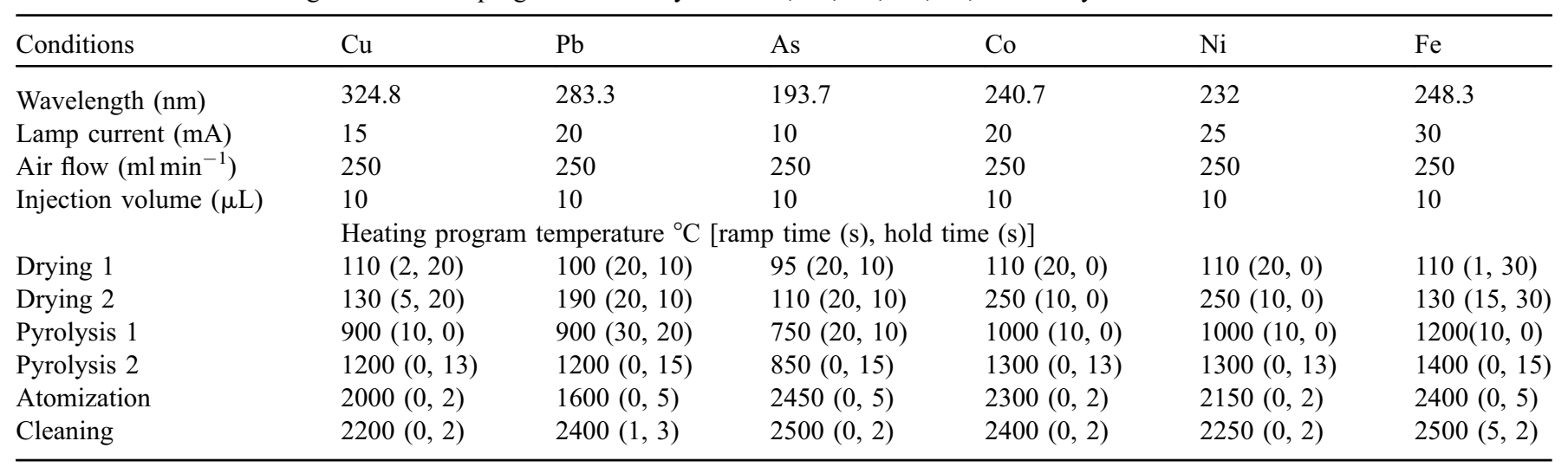

\subsubsection{Solvent extraction}

First, the dried seeds were grounded using a domestic grinder (moulinex, France) and then were sifted through number 18 mesh. Soxhlet set using n-hexane (at $60-70{ }^{\circ} \mathrm{C}, 8 \mathrm{~h}$ ) extracted the oil and collected miscella was then vacuumevaporated (Heidolph Rotavapor, Germany, $40^{\circ} \mathrm{C}$, vacuum 0.6 bar and rpm 50) to obtain the extracted oil according to Fathollahi et al. (2021).

\subsubsection{Enzyme-assisted aqueous extraction}

According to Fathollahi et al. (2021) mixture of the ground and sifted seeds with distilled water (at a ratio of 1:4 w/w) was boiled for $5 \mathrm{~min}$ and allowed to cool down to room temperature. After adjusting the optimal $\mathrm{pH}$ level for each enzyme using $0.5 \mathrm{~N}$ aqueous $\mathrm{NaOH}$ or $\mathrm{HCl}$ solutions, an amount $(2.0 \%$ by seed weight) of each enzyme (Protamex, and Celluclast $1.5 \mathrm{~L}$ ) was added to mixture. The mixture was incubated at optimal temperature of each enzyme for $4 \mathrm{~h}$ with continuous stirring at $200 \mathrm{rpm}$ followed by centrifugation (9000 rpm) for $15 \mathrm{~min}$ (Universal, PIT 320, Tehran, Iran) yielding three distinct phases:

- an oil phase;

- creamy phase;

- aqueous phase.

The top oil-rich phase was first with drawn using a micropipette, followed by the removal of the creamy and aqueous phase, leaving the meal at the bottom. To improve the oil recovery, the creamy phase was frozen at $-20^{\circ} \mathrm{C}$ for $24 \mathrm{~h}$ and thawed in a water bath at $35^{\circ} \mathrm{C}$ for $4 \mathrm{~h}$. and then centrifuged $\left(9000 \mathrm{rpm}, 30^{\circ} \mathrm{C}\right)$ for $15 \mathrm{~min}$.

All of the extracted oil samples using different extraction methods were immediately centrifuged (9000 rpm, $5 \mathrm{~min}$ ) (Universal, PIT 320, Tehran, Iran), filled in amber-colored glasses under nitrogen atmosphere and stored in the fridge.

\subsection{Preparation of cation standards}

The cation standard solutions used for calibration curves were produced by diluting a stock solution of $1000 \mathrm{mg} / \mathrm{L}$ of given cation with $10 \%(\mathrm{v} / \mathrm{v})$ nitric acid. For preparation of a mixed standard solution (containing $100 \mathrm{mg} / \mathrm{L}$ of each cation),
$2500 \mu \mathrm{L}$ of $1000 \mathrm{mg} / \mathrm{L}$ concentration of each cation was mixed in $25 \mathrm{~mL}$ volumetric balloon, and bring up to the volume with $10 \%(\mathrm{v} / \mathrm{v})$ nitric acid. The concentration ranges of the working solutions were $0-3 \mathrm{mg} / \mathrm{L}$ for all metal cations.

\subsection{Preparation of oil-cation standard samples}

To prepare spiked standard solutions with $0,0.5,1,2$ and $3 \mathrm{mg} / \mathrm{L}$ of each cation, $0,5,10,20$ and $30 \mu \mathrm{L}$ of mixed standard solution was added to $1.0 \mathrm{~g}$ of every extracted oil samples, respectively, in the test tube and then $1 \mathrm{~mL}$ of the $10 \%(\mathrm{v} / \mathrm{v})$ dilute nitric acid was added. The oil-acid mixture was shaken $(50 \mathrm{~Hz}$ for $60 \mathrm{~s})$ to mix the layers completely and then capped test tube was placed in a shaking water bath $\left(50^{\circ} \mathrm{C}, 2 \mathrm{~h}\right)$. After centrifugation $(5000 \mathrm{rpm}, 10 \mathrm{~min})$, the lower acid aqueous layer was withdrawn with a pipette and was filled to $10 \mathrm{~mL}$ by adding deionized water (Pehlivan et al., 2008). The measurements were performed with a Shimadzu 6300 graphite furnace atomic absorption spectrometry (GFAAS) (Kyoto, Japan) equipped with a heated graphite tube atomizer. Delivery of standard solutions and samples from the cup to the graphite tube performed using an ASC 6100 autosampler (Shimadzu, Kyoto, Japan). A Hettich centrifuge (ROTOFIX 32A, Kirchlengern, Germany) was used for accelerating phase separation. The instrument settings and the optimized furnace program for determination of each analyte are listed in Table 1.

\subsection{Preparation of seed samples}

0.5 gram dried Persian lime seed samples were digested with $6 \mathrm{~mL}$ of $\mathrm{HNO}_{3}(65 \%)$ (Merck, Darmstadt, Germany), $2 \mathrm{~mL}$ of $\mathrm{H}_{2} \mathrm{O}_{2}(30 \%)$ (Merck, Darmstadt, Germany) in microwave digestion system (MDS-15 Sineo, Shanghai, China) and diluted to $10 \mathrm{~mL}$ with double deionized water. A blank digest was carried out in the same way (digestion conditions for microwave system were applied as $2 \mathrm{~min}$ for $250 \mathrm{~W}, 2 \mathrm{~min}$ for $0 \mathrm{~W}, 6 \mathrm{~min}$ for $250 \mathrm{~W}, 5 \mathrm{~min}$ for $400 \mathrm{~W}, 8 \mathrm{~min}$ for $550 \mathrm{~W}$, vent: $8 \mathrm{~min}$, respectively).

\subsection{Quality control}

Recovery experiments were performed to assure the precision of the obtained data based on evaluation of trace 
Table 2. Trace element concentrations in certified reference material (NIST-SRM 1577c) and recovery of analyzed metals $(n=3)$.

\begin{tabular}{lccl}
\hline Element & Certified value & Measured value & Recovery (\%) \\
\hline $\mathrm{Fe}$ & $197.94 \mathrm{mg} / \mathrm{kg}$ & $195.76 \pm 9.33$ & 98.9 \\
$\mathrm{Cu}$ & $275.2 \mathrm{mg} / \mathrm{kg}$ & $271.34 \pm 6.14$ & 98.6 \\
$\mathrm{Co}$ & $0.3 \mathrm{mg} / \mathrm{kg}$ & $0.29 \pm 0.01$ & 97.1 \\
$\mathrm{Ni}$ & $44.5 \mu \mathrm{g} / \mathrm{kg}$ & $43.07 \pm 1.05$ & 96.8 \\
$\mathrm{~Pb}$ & $62.8 \mu \mathrm{g} / \mathrm{kg}$ & $61.73 \pm 1.31$ & 98.3 \\
$\mathrm{As}$ & $19.6 \mu \mathrm{g} / \mathrm{kg}$ & $18.90 \pm 1.11$ & 96.5 \\
\hline
\end{tabular}

metal elements in standard reference material (NIST-SRM $1577 \mathrm{c}$ bovine liver, Sigma-Aldrich, MO, USA). According to achieved results, good agreements were reported with certified values (Tab. 2).

\subsection{Statistical analysis}

All of extraction methods and analysis experiments were done in triplicate and data was reported as mean \pm standard deviation. To assess the significant effect of oil extraction methods in the levels of trace metal elements, analysis of variance (ANOVA) and Tukey's means comparing test (at 5\% significance level) were used using the Minitab ver. 19.1 software (Minitab, Pennsylvania, USA) program.

\section{Results and discussion}

\subsection{Proximate composition of Persian lime seed}

Proximate composition and trace metal elements content of Persian lime (C. latifolia) seeds are shown in Table 3. The oil, protein, carbohydrate and ash contents of the Persian lime seeds, were in the range of the data reported for Persian lime (C. latifolia) seeds (Fathollahi et al., 2021; Fathollahy et al., 2021) and Citrus limon L. (Kütdiken variety) seeds (Yilmaz and Güneser 2017). Habib et al. (1986) reported that Egyptian lime contains $42.65 \%$ lipid, $13.75 \%$ protein, $40.56 \%$ carbohydrate and $2.19 \%$ ash. The total ash content of Mitha (sweet lemon) (Citrus limetta) (Anwar et al., 2008), Eureka lemon and Kütdiken lemon (Juhaimi et al., 2016) seeds was reported as $5.50 \%, 3.24 \%$ and $3.63 \%$, respectively, which were significantly higher than our finding (1.95\%). Other citrus seeds contained total ash as follows: orange and grapefruit seeds contained $2.95-3.17 \%$ and $2.60 \%$ ash, respectively (Habib et al., 1986; El-Adawy et al., 1999), bitter orange and kinnow mandarin seeds contained $3.27 \%$ and $4.51 \%$ ash, respectively (Juhaimi et al., 2016) and Beyaz variety grapefruit seeds (Citrus paradisi L.) contained 1.28\% ash (Yilmaz et al., 2019). In general, ash content measured in this study for Persian lime seeds was lower than the values reported in the literature for citrus seeds. Different harvest year, variety, methods of analysis and oil extraction could be the reason for these differences. Juhaimi et al. (2016) reported that the concentrations of $\mathrm{Cu}$ and $\mathrm{Fe}$ in several citrus seeds was in the range of as 6.13-16.55 and 40.50-111.39 (mg/ $\mathrm{kg}$ dry matter), respectively. Among the studied citrus seeds, bitter oranges seeds were richer in terms of micro elements. Biologically, metals like iron, copper, zinc and manganese are essential metals for humans, but their excessive intake can produce toxic effects. Fathollahi et al. (2019) and Fathollahi et al. (2021) reported the oil yield of Persian lime seed using different extraction methods was as follow: solvent extraction $44.2 \pm 1.6 \%$, cold-pressing $30.4 \pm 0.6 \%$, aqueous extraction $8.86 \pm 0.8 \%$, and enzyme-assisted aqueous extraction using different enzymes (Celluclast, Pectinex, Neutrase, Alcalase, and Protamex) $17.21 \pm 0.39-31.78 \pm 0.51 \%$.

\subsection{Trace metal elements content of Persian lime seed oils}

Concentration of metal elements in edible oils is decisive due to metabolic role, toxic characteristics and effect on the quality of commercial products manufactured by the pharmaceutical, cosmetic and food preparation industries (Gonzálvez et al., 2010). In this sense, it is very important to determine whether the concentration of toxic trace metal elements are present at levels in the produced and consumed oils that might be hazardous to human health (Zeiner et al., 2005; Reddy et al., 2012). Different kinds of seeds contain different levels of trace metal elements, because of different species and variety, cultivation soil, irrigation water, stage of maturity and different proper to uptake trace metal elements (Ansari et al., 2008; Onakpa et al., 2018). The results of the analysis of trace metal elements in Persian lime seed oil samples extracted using different methods are presented in Table 4.

The reduction pattern of $\mathrm{Fe}>\mathrm{Cu}>\mathrm{Ni}>\mathrm{Co}>\mathrm{Pb}>\mathrm{As}$ was observed in all of extracted oil samples. Extraction method significantly influenced trace metal elements content $(P<0.05)$. Accordingly, cold-pressed and enzyme-assisted aqueous extracted oil samples contained the highest and lowest concentration of $\mathrm{Fe}, \mathrm{Cu}$ and $\mathrm{Pb}$, respectively. Whereas, the highest content of $\mathrm{Ni}$ and $\mathrm{Co}$ was observed in the enzymeassisted aqueous extracted oil samples. Since, trace metal elements combine to some minerals and dissolves easily in water and are up-taken by plants through water, therefore, trace metal elements in seeds are very water-soluble (Roussel et al., 2000; Lee et al., 2019). Therefore, in oil extraction methods in which water is used, such as enzyme-assisted aqueous extraction method, due to the dissolution of trace metal elements in water, less trace metal elements are transferred to the oil phase. The type of enzyme used in the enzyme-assisted aqueous extraction method also had a significant effect on the content of trace metal elements $(P<0.05)$. Accordingly, the oil samples extracted using Protamex compared to Celluclast had higher content of $\mathrm{Fe}$, $\mathrm{Co}, \mathrm{Ni}$ and $\mathrm{Pb}$. But, the content of $\mathrm{Cu}$ was higher in the oil samples extracted using Celluclast. This difference may be due to the different effects of enzymes on the constituents of seed that interact with trace metal elements. The concentration of $\mathrm{Pb}$ and $\mathrm{As}$ in all of oil samples was in the permissible levels set by Codex Alimentarius $(0.1 \mathrm{mg} / \mathrm{kg}$ in edible oils) (Alimentarius 1999). Kheirati Rounizi et al. (2021) reported that the sesame oil extraction method including traditional (Ardeh oil) and industrial method (cold-pressing method: virgin and refined sesame oil) significantly affected trace metal elements $(\mathrm{Pb}, \mathrm{Cu}, \mathrm{Cd}, \mathrm{Zn}$ and $\mathrm{As})$ content and the refining process could be considered as an efficient method in 
I. Fathollahy et al:: OCL 2021, 28, 44

Table 3. Proximate composition (\% dry weight) and trace metal elements content ( $\mathrm{mg} / \mathrm{kg}$ dry mater) of Persian lime seed.

\begin{tabular}{llllr}
\hline Moisture & Protein & Oil & Carbohydrate & Ash \\
\hline $5.13 \pm 0.17$ & $19.36 \pm 1.07$ & $45.18 \pm 1.64$ & $27.15 \pm 0.14$ & $1.95 \pm 0.05$ \\
$\mathrm{Fe}$ & $\mathrm{Cu}$ & Heavy metal (mg/kg dry mater) & Pb \\
$51.17 \pm 1.35$ & $7.19 \pm 0.17$ & $\mathrm{Ni}$ & $\mathrm{Co}$ & $0.087 \pm 0.001$ \\
\hline
\end{tabular}

ND: not detected. Note: Values given are the means of three replicates \pm standard deviation.

Table 4. Trace metal elements concentration $(\mathrm{mg} / \mathrm{kg})$ in Persian lime seed oil extracted using different methods.

\begin{tabular}{lcccc}
\hline & \multicolumn{3}{c}{ Extraction method } \\
\cline { 2 - 5 } Heavy metal & Cold-pressing & Solvent extraction & \multicolumn{2}{c}{ Enzyme-assisted aqueous extraction } \\
\cline { 2 - 5 } & & & Protamex & Celluclast \\
$\mathrm{Fe}$ & $7.3272 \pm 0.0263^{\mathrm{a}}$ & $6.9874 \pm 0.0266^{\mathrm{b}}$ & $3.25270 \pm 0.00503^{\mathrm{c}}$ & $3.0363 \pm 0.0423^{\mathrm{d}}$ \\
$\mathrm{Cu}$ & $0.35003 \pm 0.00153^{\mathrm{a}}$ & $0.30017 \pm 0.00189^{\mathrm{b}}$ & $0.28016 \pm 0.00151^{\mathrm{c}}$ & $0.30120 \pm 0.00184^{\mathrm{b}}$ \\
$\mathrm{Ni}$ & $0.04654 \pm 0.00015^{\mathrm{d}}$ & $0.06331 \pm 0.00011^{\mathrm{b}}$ & $0.06985 \pm 0.00016^{\mathrm{a}}$ & $0.05336 \pm 0.00013^{\mathrm{c}}$ \\
$\mathrm{Co}$ & $0.03648 \pm 0.00016^{\mathrm{c}}$ & $0.04245 \pm 0.00018^{\mathrm{b}}$ & $0.05455 \pm 0.00016^{\mathrm{a}}$ & $0.03342 \pm 0.00021^{\mathrm{d}}$ \\
$\mathrm{Pb}$ & $0.00891 \pm 0.00003^{\mathrm{a}}$ & $0.00283 \pm 0.00001^{\mathrm{b}}$ & $0.00251 \pm 0.00001^{\mathrm{c}}$ & $0.00234 \pm 0.00002^{\mathrm{d}}$ \\
$\mathrm{As}$ & $\mathrm{ND}$ & $\mathrm{ND}$ & $\mathrm{ND}$ & $\mathrm{ND}$ \\
\hline
\end{tabular}

ND: not detected. Note: Values given are the means of three replicates \pm standard deviation. Means with different letters within a row are significantly different at $P<0.05$ (using Tukey's Multiple Range Test).

reduction of trace metal elements. The $\mathrm{Cd}$ and $\mathrm{Zn}$ content of virgin oil was estimated lower than other samples. In Ardeh oil, except for As and $\mathrm{Zn}$, the higher amount of trace metal elements was reported in comparison with two other oils. The reduction patterns of $\mathrm{Pb}$ and $\mathrm{Cu}$ were found as refined sesame oil $<$ virgin sesame oil $<$ Ardeh oil. Compared to Kheirati Rounizi et al. (2021), in all of the Persian lime seed oil samples the content of $\mathrm{Pb}$ and As was lower, but the content of $\mathrm{Cu}$ was higher than the amount reported to different sesame oil. Based on the extraction method of Persian lime seed oil, the transfer coefficients from seed to oil for iron, copper, nickel, cobalt and lead, were 5.93-14.31\%, 3.89-4.86\%, $7.59-11.39 \%, 6.18-10.10 \%$, and $2.68-10.24 \%$, respectively. The highest and the lowest transfer coefficient was observed for iron in cold-pressing method and for lead in enzymeassisted aqueous extraction method using Celluclast, respectively. According to Lee et al. (2019) the transfer coefficients of metal elements from seeds (flaxseed, sesame and perilla) to pressed and solvent extracted oils were less than $10 \%$ other than $\mathrm{Cd}$ in perilla oils, and were up to $30 \%$ in supercriticalfluid extraction method. Hajeb et al. (2014) reported that the optimized operating conditions of supercritical-fluid extraction (SFE) (a pressure of $61 \mathrm{MPa}$, a temperature of $39.8^{\circ} \mathrm{C}$, a $\mathrm{CO}_{2}$ flow rate of $3.7 \mathrm{~mL} / \mathrm{min}$ and an extraction time of $4 \mathrm{~h}$ ) for the simultaneous elimination of toxic elements from fish oil, reduced the contents of lead, cadmium, arsenic and mercury by up to $98.3,96.1,94.9$ and $93.7 \%$, respectively. The reduction of toxic elements is highly dependent upon the type of elemental species in the fish tissue that is used. The arsenic found in the fish oil were most likely in the form of arsenolipids or might bind to cholesterol or fat-soluble vitamins species that were co-extracted with the oil during the supercritical extraction (Hajeb et al., 2014; Kohlmeyer et al., 2005). Rubio-Rodríguez et al. (2012) reported that trace amounts of cadmium, mercury, and lead were extracted together with the oil using the SFE method at a pressure of $25 \mathrm{MPa}$ and a temperature of $40^{\circ} \mathrm{C}$. However, the fish oil that was extracted using the SFE method contained $6.70 \mu \mathrm{g} / \mathrm{g}$ of arsenic.

Reddy et al. (2012) reported that element dissolution in two variety of avocado (Hass and Fuerte) oil was relatively low for traditional soxhlet, SFE and microwave extraction and relatively high for ultrasound water bath and ultra-turrax extractions. The ultrasound extraction method gave highest concentration of $\mathrm{Fe}$ in oils $(1.80-1.82 \mu \mathrm{g} / \mathrm{g})$, whilst ultraturrax method gave highest concentration of $\mathrm{Cu}$ in oils $(0.167-0.206 \mu \mathrm{g} / \mathrm{g})$. On the contrary, results of Ennoukh et al. (2017) demonstrated that the extracting by press and traditional method had no influence on the element content in argan oil and extraction method could not modify the dietary element content of the argan oil.

Minimum and maximum values of copper in Persian lime seed oil samples were 0.28016 and $0.35003 \mathrm{mg} / \mathrm{kg}$ in enzymeassisted aqueous extracted oil using Protamex and coldpressed oil. Nezirević-Nizić et al. (2020) reported that $\mathrm{Cu}$ content of cold-pressed linseed, pumpkin and sunflower oil in two different season was in range of 0.0032-0.011, $0.005-0.0169$, and $0.0083-0.089 \mathrm{mg} / \mathrm{kg}$, respectively. The $\mathrm{Cu}$ content of cold-pressed rapeseed oil from conventional and certified ecological seeds was 0.036-0.055 and $0.037-0.062 \mathrm{mg} / \mathrm{kg}$, respectively (Wroniak and Rękas, 2017). Pressed and solvent extracted oils of sunflower seeds had $\mathrm{Cu}$ content of 1.1 and $0.5 \mathrm{mg} / \mathrm{kg}$, respectively (García-González et al., 2021). According to international 
and national standards, the permitted contents of trace metal elements in edible oils: $0.1 \mathrm{ppm}(\mathrm{Cu}, \mathrm{Pb}, \mathrm{As}), 1-1.5 \mathrm{ppm}(\mathrm{Fe})$, $0.2 \mathrm{ppm}(\mathrm{Ni})$ and $0.05 \mathrm{ppm}(\mathrm{Cd})$ (Kowalewska et al., 2005). The FAO/WHO has set a limit for heavy metals intakes based on body weight. For an average adult ( $60 \mathrm{~kg}$ body weight), the provisional tolerable daily intake (PTDI) for copper, iron and lead are $3 \mathrm{mg}, 48 \mathrm{mg}$ and $214 \mu \mathrm{g} / \mathrm{g}$, respectively (FAO/WHO, 1999).

The minimum and maximum iron levels that observed in Persian lime seed oil were $3.0363 \mathrm{mg} / \mathrm{kg}$ in enzyme-assisted aqueous extracted oil using Celluclast and $7.3272 \mathrm{mg} / \mathrm{kg}$ in cold-pressed oil. Wroniak and Rękas (2017) reported $0.329-1.320 \mathrm{mg} / \mathrm{kg}$ and $0.236-1.690 \mathrm{mg} / \mathrm{kg}$ for Fe content of cold-pressed rapeseed oil from conventional and certified ecological seeds, respectively. Pressed and solvent extracted oils of sunflower seeds had Fe content of 6.0 and $22.7 \mathrm{mg} / \mathrm{kg}$, respectively (García-González et al., 2021).

The nickel content of Persian lime seed oil ranged from the minimum level $(0.04654 \mathrm{mg} / \mathrm{kg})$ in cold-pressed oil to the maximum level $(0.06985 \mathrm{mg} / \mathrm{kg})$ in enzyme-assisted aqueous extracted oil using Protamex. The WHO recommends $100-300 \mu \mathrm{g} / \mathrm{g}$ nickel for daily intake (WHO, 1993). The minimum and maximum Co levels were 0.03342 and $0.05455 \mathrm{mg} / \mathrm{kg}$ in enzyme-assisted aqueous extracted oil using Celluclast and Protamex, respectively.

The minimum and maximum lead levels of Persian lime seed oil were 0.00234 and $0.00891 \mathrm{mg} / \mathrm{kg}$ in enzyme-assisted aqueous extracted oil using Celluclast and cold-pressed oil, respectively. The level of $\mathrm{Pb}$ of cold-pressed linseed, pumpkin and sunflower oil in two different season was $0.022,0.0085-0.0122$, and $0.049-0.095 \mathrm{mg} / \mathrm{kg}$, respectively. The lead concentration of pressed and solvent extracted oils of conventional and new sunflower seeds with modified phytosterol compositions was in the range of $0.2-0.4 \mathrm{mg} / \mathrm{kg}$ (García-González et al., 2021), and $0.012-0.1 \mathrm{mg} / \mathrm{kg}$ in cold-pressed rapeseed oil from conventional and certified ecological seeds (Wroniak and Rękas 2017). WHO has established a provisional tolerable weekly intake for lead of $0.025 \mathrm{mg} / \mathrm{kg}$ of body weight (World Health Organization, 1993). Ministry of Health of the People's Republic of China $(\mathrm{MOH})$ recommended the maximum lead level for edible vegetable is $0.1 \mathrm{mg} / \mathrm{kg}(\mathrm{MOH}, 2005)$. The lead levels in all of Persian lime seed oils extracted using different method were found to be lower than legal limits. Arsenic was not detected in any of Persian lime seed oil extracted using different method. Arsenic was not detected in any of pressed and solvent extracted oils of conventional and new sunflower seeds with modified phytosterol compositions (García-González et al., 2021), but it was in the range of $0.001-0.01 \mathrm{mg} / \mathrm{kg}$ in cold-pressed rapeseed oil from conventional and certified ecological seeds (Wroniak and Rękas 2017).

Unfortunately, we could not locate trace metal elements values for citrus seed oils for a comparison. Overall, this study adds important data to the literature. In a rare case, mineral content of sweet orange (Citrus sinensis) seed oil extracted using the batch solvent extraction method was reported (Nwozo et al., 2021). The result of this study revealed that the minerals that were found in sweet orange (C. sinensis) seed oil are as follows: calcium (Ca) $15.80 \pm 0.10$, iron (Fe) $6.99 \pm 0.41$, sodium $(\mathrm{Na}) 4.60 \pm 0.30$, potassium $(\mathrm{K}) 4.80 \pm 0.20$, manganese $(\mathrm{Mn}) 0.07 \pm 0.01$, magnesium $(\mathrm{Mg}) 6.22 \pm 0.22$, zinc $(\mathrm{Zn})$
$0.28 \pm 0.02$, copper $(\mathrm{Cu}) 0.00 \pm 0.00$ and phosphorus $(\mathrm{P})$ $407.40 \pm 2.00 \mathrm{mg} / \mathrm{L}$. In comparison with sweet orange (C. sinensis) seed oil, the Persian lime (C. latifolia) seed oil extracted by cold-pressing and solvent extraction method had almost the same content of Fe (6.9874-7.3272 mg/kg versus $6.99 \pm 0.41 \mathrm{mg} / \mathrm{L})$ but enzyme-assisted aqueous extraction oil samples of Persian lime seed contained less $\mathrm{Fe}$ content $(3.0363-3.25270 \mathrm{mg} / \mathrm{kg})$. $\mathrm{Fe}$ and $\mathrm{Cu}$ concentrations in vegetable oils is known to induce oxidation and can decrease long term stability. The content of $\mathrm{Cu}$ in the solvent extracted of Persian lime (C. latifolia) seed oil $(0.30017 \pm 0.00189 \mathrm{mg} / \mathrm{kg})$ was higher than sweet orange (C. sinensis) seed oil $(0.00 \pm 0.00 \mathrm{mg} / \mathrm{L})$. The differences in the extraction method (Soxhlet extractor versus batch solvent extraction method) can be the reason for the difference in the concentration of the mentioned elements.

\section{Conclusion}

It is required to monitor the presence of toxic metal element contaminants and the quality of new oil sources such as citrus seed oil prior to consumption and industrial uses. The results showed that the extraction method of Persian lime seed oil significantly influenced the content of studied trace metal elements. Among the studied metal elements, iron and copper as pro-oxidants had the highest concentration in all extracted oils. With the exception of nickel and cobalt, the other studied metal elements had higher concentrations in cold pressed oil. The concentration of $\mathrm{Pb}$ and $\mathrm{As}$ in all of oil samples was in the permissible levels set by Codex Alimentarius. According to the results, since the level of toxic and pro-oxidants metal elements was lower in the Persian lime seed oil obtained by enzyme-assisted aqueous extraction method, so this method can produce healthier and more stable oil.

Acknowledgments. The authors would like to extend their sincere appreciation to the Asiashoor Food Industry and Trade Inc.

Conflicts of interest. The authors declare that they have no conflicts of interest in relation to this article.

\section{References}

Alimentarius C. 1999. Codex standard for named vegetable oils. Codex Stand 210: 1-13.

Ansari R, Kazi TG, Jamali MK, et al. 2008. Improved extraction method for the determination of iron, copper, and nickel in new varieties of sunflower oil by atomic absorption spectroscopy. $J$ AOAC Int 91(2): 400-407. https://doi.org/10.1093/jaoac/ 91.2.400.

Anwar F, Naseer R, Bhanger MI, Ashraf S, Talpur FN, Aladedunye FA. 2008. Physico-chemical characteristics of citrus seeds and seed oils from pakistan. J Am Oil Chem Soc 85(4): 321-330. https://doi.org/10.1007/s11746-008-1204-3.

AOCS. 1997. Official Methods and Recommended Practices of the AOCS. Champaign, IL: AOCS Press.

Lo Coco F, Ceccon L, Ciraolo L, Novelli V. 2003. Determination of cadmium(II) and zinc(II) in olive oils by derivative potentiometric stripping analysis. Food Control 14(1): 55-59. https://doi.org/ 10.1016/S0956-7135(02)00054-3. 
Dantas TNC, Neto AAD, Moura MCPA, Neto ELB, Forte KR, Leite RHL. 2003. Heavy metals extraction by microemulsions. Water Res 37(11): 2709-2717. https://doi.org/10.1016/S0043-1354(03) 00072-1.

Dugo G, La Pera L, La Torre GL, Giuffrida D. 2004. Determination of $\mathrm{Cd}(\mathrm{II}), \mathrm{Cu}(\mathrm{II}), \mathrm{Pb}(\mathrm{II})$, and $\mathrm{Zn}(\mathrm{II})$ content in commercial vegetable oils using derivative potentiometric stripping analysis. Food Chem 87(4): 639-645. https://doi.org/10.1016/j.food chem.2003.12.035.

El-Adawy TA, El-Bedawy AA, Rahma EH, Gafar AM. 1999. Properties of some citrus seeds. Part 3. Evaluation as a new source of protein and oil. Food/Nahrung 43(6): 385-391. https://doi.org/ 10.1002/(SICI) 1521-3803(19991201)43:6\%3C385::AIDFOOD385\%3E3.0.CO.

Ennoukh FE, Bchitou R, Mohammed F, Guillaume D, Harhar H, Bouhaouss A. 2017. Study of the effects of extraction methods on Argan oil quality through its metal content. Ind Crops Prod 109: 182-184. https://doi.org/10.1016/j.indcrop.2017.08.039.

FAO/WHO. 1999. Expert Committee on Food Additives, Summary and Conclusions, Fifty-third Meeting, Rome.

Fathollahi I, Farmani J, Kasaai MR, Hamishehkar H. 2019. Persian lime (Citrus Latifolia) seed oil obtained by enzyme-assisted aqueous extraction. Adv Food Sci 41(4): 85-91.

Fathollahi I, Farmani J, Kasaai MR, Hamishehkar H. 2021. Some physical properties of Persian lime (Citrus Latifolia) seeds and physicochemical properties of the seed oil as affected by solvent extraction and cold pressing methods. J Food Meas Charact 15 (2): 1169-1178. https://doi.org/10.1007/s11694-020-00712-w.

Fathollahy I, Farmani J, Kasaai MR, Hamishehkar H. 2021. Characteristics and functional properties of Persian lime (Citrus latifolia) seed protein isolate and enzymatic hydrolysates. $L W T$ 140: 110765. https://doi.org/10.1016/j.lwt.2020.110765.

García-González A, Velasco J, Velasco L, Ruiz-Méndez MV. 2021. Characterization of press and solvent extraction oils from new sunflower seeds with modified phytosterol compositions. $J$ Sci Food Agric 101(1): 101-109. https://doi.org/10.1002/jsfa.10619.

Gonzálvez A, Armenta S, de la Guardia M. 2010. Adulteration detection of argan oil by inductively coupled plasma optical emission spectrometry. Food Chem 121(3): 878-886. https://doi. org/10.1016/j.foodchem.2009.11.091.

Gopalani M, Shahare M, Ramteke DS, Wate SR. 2007. Heavy metal content of potato chips and biscuits from Nagpur City, India. Bull Environ Contam Toxicol 79(4): 384-387. https://doi.org/10.1007/ s00128-007-9256-x.

Habib MA, Hammam MA, Sakr AA, Ashoush YA. 1986. Chemical evaluation of Egyptian citrus seeds as potential sources of vegetable oils. J Am Oil Chem Soc 63(9): 1192-1196. https://doi. org/10.1007/BF02663951.

Hajeb P, Jinap S, Shakibazadeh S, Afsah-Hejri L, Mohebbi GH, Zaidul ISM. 2014. Optimisation of the supercritical extraction of toxic elements in fish oil. Food Addit Contam A Chem Anal Control Expo Risk Assess 31(10): 1712-1722. https://doi.org/ 10.1080/19440049.2014.942707.

Herbert D, Philips PJ, Strange RE. 1971. Determination of total carbohydrates. Method Microbiol 58: 209-344.

Jamali MK, Kazi TG, Arain MB, et al. 2008. A multivariate study: variation in uptake of trace and toxic elements by various varieties of Sorghum bicolor L. J Hazard Mater 158(2-3): 644-651. https://doi.org/10.1016/j.jhazmat.2008.02.007.

Juhaimi FAL, Matthäus B, Özcan MM, Ghafoor K. 2016. The physicochemical properties of some citrus seeds and seed oils. Z Naturforsch C J Biosci 71 (3-4): 79-85. https://doi.org/10.1515/ znc-2016-0004.
Kheirati Rounizi S, Akrami Mohajeri F, Moshtaghi Broujeni $\mathrm{H}$, et al. 2021. The chemical composition and heavy metal content of sesame oil produced by different methods: a risk assessment study. Food Sci Nutr 9(6): 2886-2893. https://doi.org/10.1002/ fsn3.2245.

Kohlmeyer U, Jakubik S, Kuballa J, Jantzen E. 2005. Determination of arsenic species in fish oil after acid digestion. Microchim Acta 151: 249-255. https://doi.org/10.1007/s00604-005-0406-8.

Kowalewska Z, Izgi B, Saracoglu S, Gucer S. 2005. Application of liquid-liquid extraction and adsorption on activated carbon to the determination of different forms of metals present in edible oils. Chemia Analityczna 50(6): 1007-1019. https://doi.org/10.81043/ aperta.93653.

Lee J-G, Hwang J-Y, Lee H-E, Kim T-H, Choi J-D, Gang G-J. 2019. Effects of food processing methods on migration of heavy metals to food. Appl Biol Chem 62(1): 64. https://doi.org/10.1186/ s13765-019-0470-0.

MOH. 2005. Chinese hygienic standard for edible vegetable oil (GB2716-2005). Ministry of Health of the People's Republic of China, pp. 1-2.

Nezirević-Nizić E, Čorbo S, Podrug S, Begić M. 2020. Determination of antioxidant and heavy metals in cold-pressed edible oils. IFMBE Proc 78: 295-302. https://doi.org/10.1007/978-3-03040049-1 38.

Nwozo SO, Omotayo OO, Nwawuba SU. 2021. Nutritional evaluation of sweet orange citrus sinensis seed oil. MOJ Ecol Environ Sci 6(1): 15-20. https://doi.org/10.15406/ mojes.2021.06.00208.

Onakpa MM, Njan AA, Kalu OC. 2018. A review of heavy metal contamination of food crops in Nigeria. Ann Glob Health 84(3): 488-494. https://doi.org/10.29024/aogh.2314.

Pehlivan E, Arslan G, Gode F, Altun T, Musa Özcan M. 2008. Determination of some inorganic metals in edible vegetable oils by inductively coupled plasma atomic emission spectroscopy (ICP-AES). Grasas y Aceites 59(3): 239-244. https://doi.org/ $10.3989 /$ gya.

Reddy M, Moodley R, Jonnalagadda SB. 2012. Fatty acid profile and elemental content of avocado (Persea americana Mill.) oil effect of extraction methods. J Environ Sci Health B 47(6): 529 537. https://doi.org/10.1080/03601234.2012.665669.

Roussel C, Néel C, Bril H. 2000. Minerals controlling arsenic and lead solubility in an abandoned gold mine tailings. Sci Total Environ 263 (1-3): 209-219. https://doi.org/10.1016/s0048-9697(00)00707-5.

Rubio-Rodríguez N, De Diego SM, Beltrán S, Jaime I, Sanz MT, Rovira J. 2012. Supercritical fluid extraction of fish oil from fish by-products: a comparison with other extraction methods. $J$ Food Eng 109(2): 238-248. https://doi.org/10.1016/j.jfoo deng.2011.10.011.

World Health Organization. 1993. Guidelines for drinking-water quality: volume 1: recommendations, 2nd ed. World Health Organization. https://apps.who.int/iris/handle/10665/259956.

Wroniak M, Rękas A. 2017. A preliminary study of PCBs, PAHs, pesticides and trace metals contamination in cold-pressed rapeseed oils from conventional and ecological cultivations. $J$ Food Sci Technol 54(5): 1350-1356. https://doi.org/10.1007/ s13197-017-2575-y.

Yilmaz E, Aydeniz Guneser B, Ok S. 2019. Valorization of grapefruit seeds: cold press oil production. Waste Biomass Valor 10(9): 2713-2724. https://doi.org/10.1007/s12649-018-0286-x.

Yilmaz E, Güneser BA. 2017. Cold pressed versus solvent extracted lemon (Citrus limon L.) seed oils: yield and properties. J Food Sci Technol 54(7): 1891-1900. https://doi.org/10.1007/ s13197-017-2622-8. 
Zeiner M, Steffan I, Cindric IJ. 2005. Determination of trace elements in olive oil by ICP-AES and ETA-AAS: a pilot study on the geographical characterization. Microchem $J$ 81(2): 171-176. https://doi.org/10.1016/j.microc.2004.12.002.
Zhu F, Fan W, Wang X, Qu L, Yao S. 2011. Health risk assessment of eight heavy metals in nine varieties of edible vegetable oils consumed in China. Food Chem Toxicol 49(12): 3081-3085. https://doi.org/10.1016/j.fct.2011.09.019.

Cite this article as: Fathollahy I, Pezeshki A, Sorouraddin SM. 2021. Effect of different extraction methods on trace metal elements content of Persian lime (Citrus latifolia) seed oil. OCL 28: 44. 